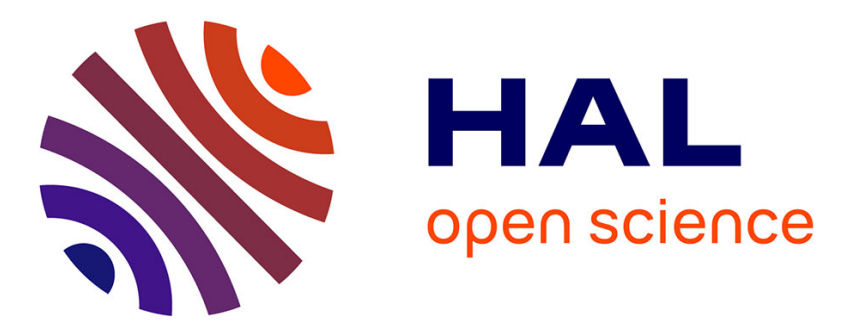

\title{
Blood loss and perioperative transfusions related to surgery for spinal tumors. Relevance of tranexamic acid
}

C. Damade, G. Tesson, V. Gilard, S. Vigny, E. Foulongne, R. Gauthé, M. Ould-Slimane

\section{- To cite this version:}

C. Damade, G. Tesson, V. Gilard, S. Vigny, E. Foulongne, et al.. Blood loss and perioperative transfusions related to surgery for spinal tumors. Relevance of tranexamic acid. Neurochirurgie, 2019, 65, pp.377 - 381. 10.1016/j.neuchi.2019.05.003 . hal-03488487

\section{HAL Id: hal-03488487 \\ https://hal.science/hal-03488487}

Submitted on 21 Dec 2021

HAL is a multi-disciplinary open access archive for the deposit and dissemination of scientific research documents, whether they are published or not. The documents may come from teaching and research institutions in France or abroad, or from public or private research centers.
L'archive ouverte pluridisciplinaire HAL, est destinée au dépôt et à la diffusion de documents scientifiques de niveau recherche, publiés ou non, émanant des établissements d'enseignement et de recherche français ou étrangers, des laboratoires publics ou privés.

\section{(ㅇ)(1) $\$$}

Distributed under a Creative Commons Attribution - NonCommerciall 4.0 International 
BLOOD LOSS AND PERIOPERATIVE TRANSFUSIONS RELATED TO SURGERY FOR SPINAL TUMORS. RELEVANCE OF TRANEXAMIC ACID

Running title: Tranexamic acid for spinal tumor surgery

PERTES SANGUINES ET TRANSFUSIONS PERI-OPERATOIRES

LIEES AUX CHIRURGIES POUR TUMEURS RACHIDIENNES.

INTERET DE L'ACIDE TRANEXAMIQUE

Titre court : Acide tranexamique et chirurgie rachidienne tumorale

Damade Camille (1), Tesson Gaëtan (2), Gilard Vianney (2,3), Vigny Solène (2), Foulongne Emmanuel (2), Gauthé Rémi (2), Ould-Slimane Mourad (2)

(1) Spine unit 1, University hospital of Rouen of Bordeaux, place Amélie-Raba-Léon, 33076 Bordeaux, France

(2) University hospital of Rouen, Spine unit, Department of orthopedic surgery, 1, rue de Germont, F76 000 Rouen, France

(3) University hospital of Rouen, Spine unit, Department of neurosurgery, 1, rue de Germont, F76 000 Rouen, France 


\section{Corresponding author:}

Rémi Gauthé,

Département de chirurgie orthopédique et traumatologie

CHU Charles nicolle,

1 rue de Germont, 76000 Rouen, France

remi.gauthe@chu-rouen.fr

Acknowledgement: none

Financial support: none

Conflict of interest: none 
BLOOD LOSS AND PERIOPERATIVE TRANSFUSIONS

RELATED TO SURGERY FOR SPINAL TUMORS. RELEVANCE

OF TRANEXAMIC ACID

PERTES SANGUINES ET TRANSFUSIONS PERI-OPERATOIRES

LIEES AUX CHIRURGIES POUR TUMEURS RACHIDIENNES.

INTÉRÊT DE L'ACIDE TRANEXAMIQUE

Word count: 3112

Number of references: 33

Number of tables: 4 


\section{Abstract}

Introduction - Tranexamic acid (TXA) has been shown to reduce bleeding. Patients with spinal tumors are fragile and acute anemia may be harmful. Tumor excision surgery is reputed to be hemorrhagic and treatment may increase thromboembolic complications. The aim of this study was to compare blood loss with or without perioperative TXA injection. The transfusion-related and postoperative complications were documents.

Method - This retrospective analysis of prospectively collected data involved 83 patients with spinal tumors who underwent decompressive surgery associated with bone fixation. Tranexamic acid was used arbitrarily in 36 of them, while the other 47 did not receive TXA. The overall, intraoperative and postoperative blood loss was recorded. Blood loss was reported relative to the number of fixed levels and the number of levels decompressed by laminectomy. Transfusions were quantified in number of red blood cell packets and erythrocyte volume. Postoperative complications were documented.

Results - Epidemiological and morphological data were similar between groups. There were no significant differences between the two groups in the overall, intraoperative, and postoperative blood loss. A significant reduction in postoperative bleeding was found in the TXA group when the volume was related to the number of decompressed levels. A significant reduction $(\mathrm{p}<0.05)$ in the volume of transfused blood was identified in the treated group. No predictor of blood loss was identified, and no additional complications occurred.

Conclusion - The efficacy of TXA appears to be moderate during spinal tumor surgery since it does not lead to a reduction in perioperative bleeding. However, a significant reduction in transfusion volume was found without an increase in complications. 
Key words - Spine surgery - Bone metastasis - Blood loss - Fracture fixation Laminectomy 


\section{Résumé}

Introduction - L'utilisation d'acide tranexamique a démontré son efficacité mais elle reste controversée pour la chirurgie des métastases rachidiennes en raison d'un risque thromboembolique accru. L'objectif était de comparer les pertes sanguines avec et sans traitement. Une description du recours transfusionnel et des complications était présentée.

Méthode - L'analyse rétrospective de données collectées prospectivement a concerné 83 patients porteurs de métastases rachidiennes ayant subi une chirurgie décompressive associée à une ostéosynthèse. L'acide tranexamique a été utilisé pour 36 d'entre eux, les 47 autres n'en ont pas reçu. Les quantités de saignement globales, per et postopératoires, le recours transfusionnel, les complications postopératoires ont été relevés.

Résultats - Les données épidémio-morphologiques étaient similaires entre les groupes. Il n'est pas apparu de différences significatives entre les deux groupes concernant les saignements globaux, peropératoires et postopératoires. Une réduction significative du saignement postopératoire apparaissait dans le groupe traité si son volume était rapporté au nombre de niveaux décomprimés. Une réduction significative $(\mathrm{p}<0,05)$ du volume de sang transfusé est apparu dans le groupe traité. Aucun facteur prédictif du volume de saignement n'a été identifié. Il n'est pas apparu significativement plus de complications. Conclusion - L'efficacité de l'ATx apparaît modérée au cours des chirurgies pour métastases rachidiennes. Elle n'entraîne pas de réduction du saignement périopératoire. Une réduction significative des quantités de transfusion est constatée sans être associée à une augmentation des complications. 
Mots clefs - Chirurgie rachidienne - Métastases osseuses - Pertes sanguines Ostéosynthèse Laminectomie 


\section{Introduction}

Tranexamic acid (TXA) is an antifibrinolytic agent used systemically to reduce bleeding during surgery. This synthetic molecule found its first applications in cardiac surgery [1-5] in the 1950s [6]. Since then, its effectiveness during hip and knee arthroplasty has been confirmed [7-9]. Its benefits have also been demonstrated for spine surgery [1014] and more particularly for the treatment of degenerative diseases of adults [15-20] or scoliosis in children and adolescents [21-24].

Surgery for tumoral lesions of the spine mainly involves the metastasis of solid tumors and hemopathies. It is associated with a greater risk of hemorrhage [25]. Intraoperative blood salvage procedures are not indicated for tumor surgery. The number of allogeneic transfusions, and their inherent risks, are therefore increased. At the same time, patients with cancer have a higher incidence of venous thrombosis [26]. For all these reasons, the perioperative use of TXA in this specific setting deserves to be evaluated [27].

The main objective of this study was to compare the blood loss observed in patients undergoing surgery for spinal tumors with and without perioperative TXA injection. Secondly, the transfusion-related and thromboembolic complications were documented. Finally, factors influencing bleeding were identified. 


\section{Material and methods}

\section{Description of the population}

This retrospective analysis of prospectively collected data involved a consecutive series of patients operated between January 2013 and December 2015. A change of practice in the use of TXA during surgery for spinal tumors occurred in July 2014. Thus, we made two subgroups based on whether or not the patients received TXA. The patients were all adults and had metastasis of a solid tumor or hematological malignancies localized within the spine. The indication for surgery was based on the risk of spinal compression or spinal deformity secondary to a pathological fracture. The surgery consisted of posterior medullary or radicular decompression associated with bone fixation. No intraoperative autotransfusion strategy was applied given the tumor context.

To homogenize the population, anterior surgery and minimally invasive percutaneous surgery were excluded. Metastasis of kidney or thyroid cancers were excluded because of their bleeding potential. Other exclusion criteria included surgeries, pregnant or lactating women, and patients with hemostatic disorders warranting preoperative pharmacological correction.

Our institutional ethics committee approved this non-interventional study (reference E2017-6). All participating subjects gave their consent for use of their anonymous data. 


\section{Technical procedure}

The surgical procedures were performed by two senior surgeons trained in spine surgery. Patients were placed in ventral decubitus with thoracic and pubic pads clearing the abdomen. A median posterior approach was used to expose two vertebrae on both sides of the treated lesions. Segmental fixation was performed by pedicular screwing. Neurological decompression included laminectomy and arthrectomy or even pediculectomy if necessary. Curettage of the tumor lesion was performed for decompression and to obtain histological samples. The surgical site was closed after having disposed of suction drainage.

TXA injection was performed by the anesthesia team at a dose of $15 \mathrm{mg} / \mathrm{kg}$ at the time of induction and continued with the same dose administered continuously over 8 hours. The need for a TXA intraoperative injection was determined based on comorbidities and the expected risk of bleeding. The contraindications to TXA injection were an abnormal fibrinolytic process with disseminated intravascular coagulation, severe renal insufficiency (creatinemia greater than $250 \mu \mathrm{mol} / \mathrm{l}$ ) or convulsion history. History of venous or arterial thrombosis was not an exclusion criterion. The surgical indication was not modified by the use of TXA. All the patients involved in this study had curare injected with an electronic syringe and maintained throughout the procedure. The blood pressure objective was a mean arterial pressure between 65 and $75 \mathrm{~mm} \mathrm{Hg}$.

Transfusion was standardized using hemoglobin $(\mathrm{Hb})$ thresholds collected by $\beta$ hemoglobin photometer $\left(\mathrm{HemoCue}^{\circledR}\right.$ Radiometer, Neuilly-Plaisance, France) intraoperative or postoperative blood counts. The cutoff was $8 \mathrm{~g} / \mathrm{dl}$ in patients with no history of ischemic heart disease. In coronary patients, this threshold was $9 \mathrm{~g} / \mathrm{dl}$. The 
transfusion objective was $10 \mathrm{~g} / \mathrm{dl}$. Each unit of packed red blood cells (PRBCs) is expected to raise circulating $\mathrm{Hb}$ by approximately $1 \mathrm{~g} / \mathrm{dl}$.

During the postoperative period, patients were lifted on day 1 and walking was encouraged when possible to limit the risk of deep vein thrombosis.

\section{Evaluation criteria}

The primary endpoint was perioperative blood loss. The intraoperative volume was quantified by the suction device and the postoperative volume quantified by drainage. This blood loss was related to the number of fixed vertebral levels and the extent of laminectomy.

There were multiple secondary endpoints. The number of transfusions was quantified as the number of PRBCs and erythrocyte volumes administered from the procedure to the time of discharge. The Hb level was determined before the procedure and on days 1 and 3 postoperatively. Postoperative complications, particularly thromboembolic complications with paraclinical confirmation, and length of hospital stay were collected. The injury criteria used were the number and location of the vertebrae involved, the clinical neurological status of the patient according to the American Spinal Injury Association classification (ASIA score). Surgical criteria included operative time, expansion of decompression and fixation. Other epidemiological data were collected such as sex, age and body mass index (BMI). They also included medical history such as the use of anticoagulants or antiplatelet agents and the origin of the primary tumor when identified.

\section{Statistical analysis}


Statistical analysis was performed using $\mathrm{JMP}^{\circledR}$ software version 6.0.3 (SAS Institute Inc., Cary, NC, 1989-2007). Quantitative variables (age, BMI, Hb, operative time, number of injured vertebrae, number of fixed levels, number of levels released, intraoperative blood loss, volume of blood in the drains, total bleeding volume, variation in bleeding rates, pre- and postoperative $\mathrm{Hb}$, number of PRBC units transfused, volume of transfused erythrocyte) were considered as continuous variables and expressed as mean \pm standard deviation. Qualitative variables (sex, history, anticoagulant or antiplatelet use, ASIA score, primary lesions, spinal lesions, affected vertebrae, single or multiple lesions, presence of bone fixation, TXA injection, postoperative complications) were expressed as percentages. Comparisons of continuous variables were performed with Student's $t$ test after confirming the data were normally distributed using the Shapiro-Wilk test. In case of non-normal distribution, the nonparametric Mann-Whitney test was used. An $X^{2}$ test or Fisher exact test was used to compare qualitative variables. 


\section{Results}

\section{Patient population}

The study involved 83 patients, 36 of whom (43.4\%) received TXA injections (TXA group). The other 47 patients (56.6\%) did not receive antifibrinolytics (No TXA group). The mean age was 61.7 years $( \pm 13.4)$ with a predominance of women (sex ratio 0.6 ). Other epidemiological and morphological data are listed in Table 1. The intake of antiplatelet agents $(19.3 \%, \mathrm{n}=16)$ and anticoagulants $(4.8 \%, \mathrm{n}=4)$ was noted; $15.7 \%$ of patients $(\mathrm{n}=13)$ had a prior arterial thrombosis.

Table 2 lists the primary tumor origins. A predominance of thoracic $(70.8 \%, \mathrm{n}=85)$ and lumbar $(25.8 \%, \mathrm{n}=31)$ locations was reported (Table 1). Multiple metastatic vertebrae per patient were identified in $34.9 \%$ of cases $(n=29)$. The average operating time was 133 minutes $( \pm 35)$. Bone fixation was associated with 1 to 5 levels of laminectomy.

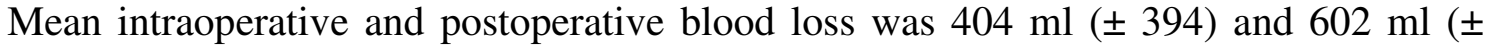
280), respectively (Table 3). The transfusion procedure resulted in an average prescription of $1.5 \mathrm{PRBC}$ units $( \pm 1.8)$, i.e. an $\mathrm{RBC}$ volume of $450 \mathrm{ml}( \pm 522)$. The average duration of hospitalization was 11 days $( \pm 10.8)$.

\section{Impact of TXA}

The two subgroups were epidemiologically and morphologically similar (Table 1). However, the TXA group had significantly more lung cancers $(p<0.01)$ and preoperative neurological deficit $(\mathrm{p}<0.001)$.

There was no significant difference between the two groups in the overall $(\mathrm{p}=0.62)$, intraoperative $(\mathrm{p}=0.85)$ and postoperative $(\mathrm{p}=0.17)$ blood loss. On the other hand, the 
rate of postoperative transfusion was significantly lower in the TXA group based on the number of transfused PRBC units $(\mathrm{p}<0.05)$ and the $\mathrm{RBC}$ volume $(\mathrm{p}<0.05)$. Postoperative bleeding was statistically less when related to the number of decompressed laminectomy levels $(\mathrm{p}<0.01)$ in the TXA group. This difference was not found when the bleeding was related to the number of bone fixation levels. There was no significant difference between the groups in the complication rate and length of hospital stay. There were no anaphylactic events or increased thromboembolism in TXA group.

No statistically significant correlation was identified between bleeding and epidemiological, morphological, tumor or surgical parameters in both the univariate and multivariate analysis. 


\section{Discussion}

Several methods to reduce the consequences of perioperative blood loss are available. These include preoperative hematopoietic stimulations, autologous transfusions, radioembolization, controlled hypotension, local and general hemostatic products, intra- and postoperative blood collection, or a combinations of these strategies [28].

TXA, a synthetic analog of the amino acid lysine, has proven to be a cost-effective method for decreasing transfusion rates and avoiding complications associated with low blood volume during spinal deformity surgery [29]. Its effectiveness has been proven in several applications $[1-4,7,8]$. This is particularly the case for spine surgery according to two meta-analysis studies [30,31]. Transfusions are common during these surgeries. Reducing their number is an important goal as they are associated with potentially severe complications [31].

Studies of pathologies such as lumbar ductal stenosis $[18,20,32]$ or kyphotic and scoliotic deformities $[15,22]$ confirm the efficacy of TXA. On the other hand, there is little recent data on surgery for spinal tumors [27]. However, these procedures are known to be hemorrhagic and are often performed on frail subjects in whom acute postoperative anemia could be harmful. TXA was minimally effective in the metastatic context of our study. In fact, there was no significant reduction in overall blood loss or even blood loss in the pre- and postoperative periods. This findings corroborates the results of Bednar et al. [27], drawn from a small sample.

However, there were some positive aspects to TXA use. A significant reduction in transfusions was found in the TXA group. This may be explained by less frequent or shallower postoperative anemia, in which patients less frequently reach the established threshold for transfusion. Postoperative bleeding appeared to be reduced in the TXA 
group when the number of laminectomy levels increased. This suggests that a large amount of blood loss is needed to highlight TXA efficacy. In both groups, there were no additional thromboembolic events despite the increased risk associated with progressive cancers. There were no seizures, although this was considered more frequent with TXA in a prior study [33]. There were no anaphylactic events.

This confirms the data reported by the large prospective randomized CRASH 2 study [34], which found no additional thromboembolic morbidity in a placebo group or a TXA group $(\mathrm{p}=0.084)$. Contraindications related to thromboembolic risk initially described for this molecule are no longer a limit to its use. All these factors lead us to consider TXA as useful and applicable for reducing the number of transfusions related to spinal tumor surgery.

Several limitations impact the validity of our results. The 83 patients included constitute a relatively small cohort which may explain the lack of significance in some of the tests, especially since the amount of blood loss was low. The effectiveness of TXA for spinal metastasis surgery is probably difficult to demonstrate because the amounts of blood loos is, on average, less than for scoliosis surgery for example. The assessment of blood loss was based on quantification of aspirated blood volumes. This method is associated with inaccuracies. However, the same method was used for all the subjects studied. Our cohort had several subgroups of primary tumors that we did not want to subdivide in order to maintain an analyzable number. By chance, lung cancer was predominant in the group without TXA (22 vs 7). The predominance of arterial thrombosis comorbidity in the No TXA group (12 vs 1) could be considered another confounding factor. Metastasis of kidney and thyroid cancers underwent radio-embolization before surgery. They were not excluded from this study because this strategy is current practice. 
Finally, this retrospective study compared patients without randomization but with the decision to inject TXA based on medical criteria linked to the patient's hemorrhagic risk. The choice of TXA injection subjectively belonged to the anesthetist on nonprotocol criteria. However, the characteristics of the two groups were not significantly different before the surgical procedure. TXA was used arbitrarily for some patients without objective criteria before this retrospective study was set up. 


\section{Conclusion}

While TXA appears compatible with spinal metastasis surgery, its use is not associated with a reduction in perioperative blood loss. On the other hand, it significantly reduced the number of transfusions related to the procedure. In parallel, it does not cause additional complications including thromboembolic ones. 


\section{References}

[1] Bulutcu FS, Ozbek U, Polat B, Yalçin Y, Karaci AR, Bayindir O. Which may be effective to reduce blood loss after cardiac operations in cyanotic children: tranexamic acid, aprotinin or a combination? Paediatr Anaesth 2005;15:41-6.

[2] Chauhan S, Das SN, Bisoi A, Kale S, Kiran U. Comparison of epsilon aminocaproic acid and tranexamic acid in pediatric cardiac surgery. J Cardiothorac Vasc Anesth 2004;18:141-3.

[3] Fergusson DA, Hébert PC, Mazer CD, Fremes S, MacAdams C, Murkin JM, et al. A comparison of aprotinin and lysine analogues in high-risk cardiac surgery. N Engl J Med 2008;358:2319-31.

[4] Reid RW, Zimmerman AA, Laussen PC, Mayer JE, Gorlin JB, Burrows FA. The efficacy of tranexamic acid versus placebo in decreasing blood loss in pediatric patients undergoing repeat cardiac surgery. Anesth Analg 1997;84:990-6.

[5] Schouten ES, van de Pol AC, Schouten ANJ, Turner NM, Jansen NJG, Bollen CW. The effect of aprotinin, tranexamic acid, and aminocaproic acid on blood loss and use of blood products in major pediatric surgery: a meta-analysis. Pediatr Crit Care Med 2009;10:182-90.

[6] Okamoto S, Hijikata-Okunomiya A, Wanaka K, Okada Y, Okamoto U. Enzymecontrolling medicines: introduction. Semin Thromb Hemost 1997;23:493-501.

[7] Kagoma YK, Crowther MA, Douketis J, Bhandari M, Eikelboom J, Lim W. Use of antifibrinolytic therapy to reduce transfusion in patients undergoing orthopedic surgery: a systematic review of randomized trials. Thromb Res 2009;123:687-96. [8] Zufferey P, Merquiol F, Laporte S, Decousus H, Mismetti P, Auboyer C, et al. Do antifibrinolytics reduce allogeneic blood transfusion in orthopedic surgery? 
Anesthesiology 2006;105:1034-46.

[9] Hynes M, Calder P, Scott G. The use of tranexamic acid to reduce blood loss during total knee arthroplasty. Knee 2003;10:375-7.

[10] Farrokhi MR, Kazemi AP, Eftekharian HR, Akbari K. Efficacy of prophylactic low dose of tranexamic acid in spinal fixation surgery: a randomized clinical trial. $\mathbf{J}$ Neurosurg Anesthesiol 2011;23:290-6.

[11] Liu J, Peng H, Shen J, Qiu G. A meta-analysis of the effectiveness and safety of using tranexamic acid in spine surgery. Zhonghua Wai Ke Za Zhi 2010;48:937-42.

[12] Wong J, El Beheiry H, Rampersaud YR, Lewis S, Ahn H, De Silva Y, et al. Tranexamic Acid reduces perioperative blood loss in adult patients having spinal fusion surgery. Anesth Analg 2008;107:1479-86.

[13] Xie J, Lenke LG, Li T, Si Y, Zhao Z, Wang Y, et al. Preliminary investigation of high-dose tranexamic acid for controlling intraoperative blood loss in patients undergoing spine correction surgery. Spine J 2015;15:647-54.

[14] Raksakietisak M, Sathitkarnmanee B, Srisaen P, Duangrat T, Chinachoti T, Rushatamukayanunt P, et al. Two Doses of Tranexamic Acid Reduce Blood Transfusion in Complex Spine Surgery: A Prospective Randomized Study. Spine 2015;40:E1257-1263.

[15] Baldus CR, Bridwell KH, Lenke LG, Okubadejo GO. Can we safely reduce blood loss during lumbar pedicle subtraction osteotomy procedures using tranexamic acid or aprotinin? A comparative study with controls. Spine 2010;35:235-9. [16] Elgafy H, Bransford RJ, McGuire RA, Dettori JR, Fischer D. Blood loss in major spine surgery: are there effective measures to decrease massive hemorrhage in major spine fusion surgery? Spine 2010;35:S47-56. 
[17] Elwatidy S, Jamjoom Z, Elgamal E, Zakaria A, Turkistani A, El-Dawlatly A. Efficacy and safety of prophylactic large dose of tranexamic acid in spine surgery: a prospective, randomized, double-blind, placebo-controlled study. Spine 2008;33:257780.

[18] Endres S, Heinz M, Wilke A. Efficacy of tranexamic acid in reducing blood loss in posterior lumbar spine surgery for degenerative spinal stenosis with instability: a retrospective case control study. BMC Surg 2011;11:29.

[19] Gill JB, Chin Y, Levin A, Feng D. The use of antifibrinolytic agents in spine surgery. A meta-analysis. J Bone Joint Surg Am 2008;90:2399-407.

[20] Wang Q, Liu J, Fan R, Chen Y, Yu H, Bi Y, et al. Tranexamic acid reduces postoperative blood loss of degenerative lumbar instability with stenosis in posterior approach lumbar surgery: a randomized controlled trial. Eur Spine J 2013;22:2035-8. [21] Dhawale AA, Shah SA, Sponseller PD, Bastrom T, Neiss G, Yorgova P, et al. Are antifibrinolytics helpful in decreasing blood loss and transfusions during spinal fusion surgery in children with cerebral palsy scoliosis? Spine 2012;37:E549-555. [22] Newton PO, Bastrom TP, Emans JB, Shah SA, Shufflebarger HL, Sponseller PD, et al. Antifibrinolytic agents reduce blood loss during pediatric vertebral column resection procedures. Spine 2012;37:E1459-1463.

[23] Shapiro F, Zurakowski D, Sethna NF. Tranexamic acid diminishes intraoperative blood loss and transfusion in spinal fusions for duchenne muscular dystrophy scoliosis. Spine 2007;32:2278-83.

[24] Yagi M, Hasegawa J, Nagoshi N, lizuka S, Kaneko S, Fukuda K, et al. Does the intraoperative tranexamic acid decrease operative blood loss during posterior spinal fusion for treatment of adolescent idiopathic scoliosis? Spine 2012;37:E1336-1342. 
[25] Shimizu K, Shikata J, Iida H, Iwasaki R, Yoshikawa J, Yamamuro T. Posterior decompression and stabilization for multiple metastatic tumors of the spine. Spine $1992 ; 17: 1400-4$.

[26] Heit JA, Silverstein MD, Mohr DN, Petterson TM, O’Fallon WM, Melton LJ. Risk Factors for Deep Vein Thrombosis and Pulmonary Embolism: A Population-Based Case-Control Study. Arch Intern Med 2000;160:809-15.

[27] Bednar DA, Bednar VA, Chaudhary A, Farrokhyar F, Farroukhyar F. Tranexamic acid for hemostasis in the surgical treatment of metastatic tumors of the spine. Spine 2006;31:954-7.

[28] Tobias JD. Strategies for minimizing blood loss in orthopedic surgery. Semin Hematol 2004;41:145-56.

[29] Slattery C, Kark J, Wagner T, Verma K. The Use of Tranexamic Acid to Reduce Surgical Blood Loss: A Review Basic Science, Subspecialty Studies, and The Evolution of Use in Spine Deformity Surgery. Clin Spine Surg 2019;32:46-50.

[30] Li Z-J, Fu X, Xing D, Zhang H-F, Zang J-C, Ma X-L. Is tranexamic acid effective and safe in spinal surgery? A meta-analysis of randomized controlled trials. Eur Spine J 2013;22:1950-7.

[31] Yang B, Li H, Wang D, He X, Zhang C, Yang P. Systematic review and metaanalysis of perioperative intravenous tranexamic acid use in spinal surgery. PLoS One 2013;8:e55436.

[32] Shi H, Ou Y, Jiang D, Quan Z, Zhao Z, Zhu Y. Tranexamic acid reduces perioperative blood loss of posterior lumbar surgery for stenosis or spondylolisthesis: A randomized trial. Medicine (Baltimore) 2017;96:e5718.

[33] Casati V, Romano A, Novelli E, D’Angelo A. Tranexamic acid for trauma. 
Lancet 2010;376:1049-50; author reply 1050-1051.

[34] CRASH-2 trial collaborators, Shakur H, Roberts I, Bautista R, Caballero J, Coats T, et al. Effects of tranexamic acid on death, vascular occlusive events, and blood transfusion in trauma patients with significant haemorrhage (CRASH-2): a randomised, placebo-controlled trial. Lancet 2010;376:23-32. 
Table 1: Population and surgery characteristics with comparison between the two groups

\begin{tabular}{|c|c|c|c|c|}
\hline & $\begin{array}{c}\text { Total } \\
(\mathbf{N}=\mathbf{8 3})\end{array}$ & $\begin{array}{c}\text { TXA group } \\
(\mathbf{N}=36 ; \mathbf{4 3 . 4 \% )}\end{array}$ & $\begin{array}{l}\text { No TXA group } \\
(\mathrm{N}=47 ; 56.6 \%)\end{array}$ & $\mathbf{p}$ \\
\hline \multicolumn{5}{|c|}{ Epidemiological and morphological data } \\
\hline Age at surgery (years) & $61.7 \pm 13.3$ & $61.9 \pm 14.7$ & $61.5 \pm 14.7$ & 0.88 \\
\hline Sex ratio (Female / Male) & 0.6 & 0.5 & 0.7 & 0.08 \\
\hline BMI $\left(\mathrm{kg} / \mathrm{m}^{2}\right)$ & $24.9 \pm 5.0$ & $24.3 \pm 4.3$ & $25.1 \pm 5.5$ & 0.48 \\
\hline Number of spinal lesions & $1.4 \pm 0.7$ & $1.4 \pm 0.6$ & $1.4 \pm 0.7$ & 0.92 \\
\hline Multiple spinal tumors & $29(34.9)$ & $13(36.1)$ & $16(34.0)$ & 0.64 \\
\hline $\begin{array}{cc}\text { ASIA score } \\
- & \text { A } \\
- & \text { B } \\
- & \text { C } \\
- & \text { D } \\
- & \text { E }\end{array}$ & $\begin{array}{c}1(1.2) \\
1(1.2) \\
16(19.3) \\
1(1.2) \\
64(77.1)\end{array}$ & $\begin{array}{c}1(2.8) \\
0(0) \\
7(19.4) \\
1(2.8) \\
27(75.0)\end{array}$ & $\begin{array}{c}0(0) \\
1(2.1) \\
9(19.1) \\
0(0) \\
37(78.7)\end{array}$ & 0.35 \\
\hline \multicolumn{5}{|l|}{ Comorbidities } \\
\hline Arterial thrombosis & $13(15.7)$ & $1(2.8)$ & $12(25.5)$ & 0.005 \\
\hline Venous thrombosis & $0(0)$ & $0(0)$ & $0(0)$ & \\
\hline Seizure & $1(1.2)$ & $0(0)$ & $1(2.1)$ & 0.40 \\
\hline Antiplatelet agent & $16(19.3)$ & $6(16.7)$ & $10(21.2)$ & 0.57 \\
\hline Anticoagulant & $4(4.8)$ & $1(2.8)$ & $3(6.4)$ & 0.50 \\
\hline \multicolumn{5}{|l|}{ Operative data } \\
\hline Operative time (minutes) & $133 \pm 35$ & $131 \pm 37$ & $133 \pm 34$ & 0.77 \\
\hline Associated fixation & $83(100)$ & $36(100)$ & $47(100)$ & \\
\hline - Number of levels & $5.8 \pm 2.3$ & $6.0 \pm 1.7$ & $5.6 \pm 2.3$ & 0.42 \\
\hline Extent of laminectomy (stage) & $2.3 \pm 0.8$ & $2.3 \pm 0.7$ & $2.3 \pm 0.9$ & 0.93 \\
\hline Hospital stay (days) & $11.0 \pm 10.8$ & $11.0 \pm 9.6$ & $11.0 \pm 11.8$ & 0.92 \\
\hline \multicolumn{5}{|l|}{ Complications } \\
\hline Early complication ( $<7$ days $)$ & $8(9.6)$ & $2(5.6)$ & $6(12.8)$ & 0.33 \\
\hline Late complication (> 7 days) & $18(21.7)$ & $7(19.4)$ & $11(23.4)$ & 0.81 \\
\hline Level involved & $(\mathbf{N}=120)$ & $(\mathrm{N}=51 ; 42.5 \%)$ & $(\mathrm{N}=69 ; 57.5)$ & \\
\hline - Cervical & $4(3.3)$ & $0(0)$ & $4(5.8)$ & \\
\hline - Thoracic & $85(70.8)$ & $41(80.4)$ & $44(63.8)$ & \\
\hline - Lumbar & $31(25.8)$ & $10(19.6)$ & $21(30.4)$ & \\
\hline
\end{tabular}


Table 2: Primary tumor distribution for the two groups

\begin{tabular}{lccc}
\hline Primary tumors & $\begin{array}{c}\mathbf{N}(\mathbf{\%}) \\
(\mathbf{N}=\mathbf{8 3})\end{array}$ & $\begin{array}{c}\text { TXA group } \\
(\mathbf{N}=\mathbf{3 6} ; \mathbf{4 3 . 4 \%})\end{array}$ & $\begin{array}{c}\text { No TXA group } \\
(\mathbf{N}=\mathbf{4 7} ; \mathbf{5 6 . 6 \%})\end{array}$ \\
\hline Lung & $29(34.9)$ & $7(19.4)$ & $22(46.8)$ \\
Breast & $24(28.9)$ & $14(38.9)$ & $10(21.3)$ \\
Prostate & $7(8.4)$ & $4(11.1)$ & $3(6.4)$ \\
Multiple myeloma & $4(4.8)$ & $2(5.6)$ & $2(4.3)$ \\
Urinary & $4(4.8)$ & $3(8.3)$ & $1(2.1)$ \\
Colorectal & $3(3.6)$ & $1(2.8)$ & $2(4.3)$ \\
Upper airway & $2(2.4)$ & $0(0)$ & $2(4.3)$ \\
Testicle & $2(2.4)$ & $1(2.8)$ & $1(2.1)$ \\
Other & $8(9.6)$ & $4(11.1)$ & $4(8.6)$ \\
& & & \\
\hline
\end{tabular}

TXA: Tranexamic acid 
Table 3: Blood loss comparison between the two groups

\begin{tabular}{|c|c|c|c|c|}
\hline & $\begin{array}{l}\text { Overall } \\
(\mathrm{N}=\mathbf{8 3})\end{array}$ & $\begin{array}{c}\text { TXA group } \\
(\mathrm{N}=\mathbf{3 6} ; \mathbf{4 3 . 4 \% )}\end{array}$ & $\begin{array}{l}\text { No TXA group } \\
(\mathrm{N}=47 ; 56.6 \%)\end{array}$ & $\mathbf{p}$ \\
\hline \multicolumn{5}{|l|}{ Blood loss (ml) } \\
\hline Intraoperative & $401 \pm 392$ & $444 \pm 356$ & $370 \pm 419$ & 0.85 \\
\hline Postoperative & $604 \pm 279$ & $568 \pm 250$ & $631 \pm 299$ & 0.17 \\
\hline Total & $1006 \pm 513$ & $1018 \pm 438$ & $1001 \pm 564$ & 0.62 \\
\hline \multicolumn{5}{|c|}{ Bleeding ratio by laminectomy level } \\
\hline Intraoperative & $193 \pm 192$ & $200 \pm 174$ & $187 \pm 218$ & 0.52 \\
\hline Postoperative & $294 \pm 163$ & $265 \pm 146$ & $317 \pm 209$ & 0.01 \\
\hline Total & $487 \pm 269$ & $468 \pm 223$ & $512 \pm 336$ & 0.15 \\
\hline \multicolumn{5}{|c|}{ Bleeding ratio by fixation level } \\
\hline Intraoperative & $81 \pm 76$ & $79 \pm 61$ & $83 \pm 142$ & 0.55 \\
\hline Postoperative & $111 \pm 52$ & $99 \pm 45$ & $120 \pm 59$ & 0.17 \\
\hline Total & $192 \pm 93$ & $177 \pm 75$ & $203 \pm 184$ & 0.34 \\
\hline \multicolumn{5}{|l|}{ Hemoglobin decrease } \\
\hline Day 1 vs. preoperative & $-0.74 \pm 1.7$ & $-0.75 \pm 1.7$ & $-0.76 \pm 1.9$ & 0.71 \\
\hline Day 3 vs. preoperative & $-1.08 \pm 1.7$ & $-1.12 \pm 1.8$ & $-1.06 \pm 1.7$ & 0.69 \\
\hline $\begin{array}{l}\text { Red blood cell units } \\
\text { transfused }\end{array}$ & $1.5 \pm$ & $1.2 \pm 1.4$ & $1.8 \pm 2.3$ & 0.04 \\
\hline Erythrocyte volume (ml) & $450 \pm 522$ & $348 \pm 411$ & $528 \pm 678$ & 0.04 \\
\hline
\end{tabular}

